\title{
BIONICS APLIED IN PRODUCT DEVELOPMENT
}

\section{A BIÔNICA APLICADA NO DESENVOLVIMENTO DE PRODUTOS}

\section{Wiliam Jeremias dos Santos}

Laboratório de Engenharia de Materiais, Universidade do Extremo Sul Catarinense CEP: 88804-000, Avenida Universitária, Criciúma, SC, Brasil

e-mail:wiliamjji@ibest.com.br

\begin{abstract}
In the recent years seems to be increasing the interest of engineers in the nature design concepts, it is because based biological systems and elements from nature we can find technological solutions to improve products and process. In summary, it is bionics. In this paper are presented bionics definition and concepts, its potential applications and finally, the methodology to apply bionics in the development of a product.

Keywords: Product. Bionics. Biodesign.
\end{abstract}

\section{RESUMO}

Nos últimos anos há evidências do aumento de interesse dos engenheiros quanto aos conceitos de design da natureza, isto é, devido aos sistemas biológicos e aos elementos da natureza, podendo assim encontrar soluções tecnológicas para melhorar produtos e processos. Em resumo, isto é biônica. Neste trabalho são apresentados definições e conceitos biônicos, suas aplicações potenciais e finalmente, a metodologia para se aplicar biônica no desenvolvimento de produtos.

Palavras-chave: Produto. Biônica. Biodesign

Certainly, when Leonardo da Vinci was inspired in birds, bats and insects in the Middle Age, studying their anatomy and movements during their flight with the aim of building his "flying machine" he did not know the term bionics, although he was applying the concepts of this new science. He was not concerned with the interdisciplinary (merging biological science knowledge with engineering) or with the environmental policy of his city, which could scold their projects by 
environmental legislation. His interest was to realize the dream of flying, and being an authority on art and nature themes, he knew more than anyone that good projects should have an intimate dialogue between the physical shape of the object and the environment. This would result in a balance avoiding wasted material, energy and expenditure of time.

More than 300 years later, Otto Lilienthal built and flew in the gliding machines that were also patterned after birds (BENYUS, 1997). In a simple way bionics can be defined as the study of biological systems for implementation and improvement of products and processes. The thought of bionics is based on the natural evolvement and co-evolvement. The bionics tends to imitate certain functions of creatures in technology. The thinking that sees building bridges between the biology and technology is valid for solving technological issues. Based on the biological laws, we can easily find the technological solution, which may right meet the nature law. (SUN and XIAO, 2007).

Benyus (1997) give us a similar definition. For him, bionics is a science that teaches us to observe the phenomena and natural elements to extract their models applicable in any field of science. Propose and create under its influence, is to consider nature as mentor, following its rules and models. In this article the terms bionics, biomimetics and biomimicry are used as the same signification, these words are synonymous, but according to area of interest are used one or another one word.

Perhaps it is not surprising that early aeronautical engineers were inspired by nature given that the performance gap was so large and obvious. Because birds can fly and we can not, only the most foolhardy or arrogant individual would design a flying craft without some reference to natural analogs. Most engineering projects, however, take place successfully without any explicit reference on the nature, in large part because natural analogs do not exist for most mechanical devices (DICKINSON, 1999).

Besides aviation, another classics examples of bionics application are the Velcro (VElours-CROchet). As the background of the invention, in the early 1940's, Swiss inventor George de Mestral noticed that cockleburs had a tendency to attach themselves to clothing, and animal fur. His inventor's curiosity led him to study the burrs under a microscope, where he discovered their natural hook-like shape. This was to become the basis for a unique, two-sided fastener - one side with stiff "hooks" like the burrs and the other side with the soft "loops" like the fabric of his pants. The result was VELCRO ${ }^{\circledR}$ brand hook and loop fasteners, named for the French words "velour" and "crochet." (PATENTS ONLINE, 2011).

Part of theory of infrared was an adaptation of mechanisms observed in the viper rattlesnake (FAVRET, 2008).

The benefits of the biomimetics can be seen in many applications, including multifunctional materials, improved drugs, robotics and others. Examples of that are the biodegradable fibers, ceramics, plastics and a lot of chemical products (COHEN, 2005). 
As Dickinson (1999) through bionics it is possible to construct complicated structures at the molecular or near molecular level. Examples include buckballs, nanotubes, and myriad of micro-electromechanical devices (MEMs) constructed with technology derived from silicon chip industry. Integrated circuits themselves play a role in bionics projects aimed at constructing smart materials or mimicking the movement, behavior, and cognition of animals. It is important reason for the growing interest in bionics fabrication methods.

Increasingly there is a need for projects optimized for the cost, raw material, energy, labor and safety. The selection of materials in the stage of project is the focal point, whatever the technology industry is key to a good project. The shape of product should connect with the technological aspects as strength, durability, chemical and physical properties. Therefore, in the project stage, does not often give due importance to these factors; the construction industry, for example, projects are massive masonry and overdimensioned resulting in increased cost and great demand for natural resources (ASHBY, 1999).

We can improve products and processes observing the plants and animals' structures, seaweeds textures, reptiles leather and rand fish can pose practical solutions to the solid surfaces under friction and abrasion. Through the process of evolution, organisms have experimented with form and function of at least 3 billion years before the first human manipulations of stone, bone, and antler (DICKINSON, 1999). The natural structures do not have huge format or right angles, but light and subtle forms; timber, for example, is a lightweight and durable material composed by cellulose fibers or even targeted as the structure of wood (VASCONCELOS, 2000).

A small alteration in the form of a product can completely change their characteristics of an object; this variation may define the ownership of internal resistance of the material. Any change in a pro change in a project should always be inspired in nature, because its works in the simplest way, with greater efficiency and harmony.

The redesign of a product, for instance, a package, must to consider every phases of the life cycle design - LCD, identifications problems and objectives that generate an increasing sustainability (MEIRA and HEMANN, 2007)

Then, we can bring a number of advantages as, reducing energy consumption in the manufacturing process, minimizing heat loss, better economics and, consequently, reducing environmental impact by choosing the most suitable materials, reducing the consumption of raw materials and energy.

It is essential to know that, if the design is bionic, can be optimized, but the reasoning is generic, serve as a guide to produce better products. For instance, a bird flaps its wings to fly, but it does not mean that to improve the design of an aircraft, its necessary to use the same mechanism (DICKINSON, 1999).

Several other simple analogies can be done and we can take advantage of product redesign solutions. It very is important that many factors through models simulation can studied, theoretically and experimentally, so we can always get closer 
to the state-of-art.

To apply bionics in the project of a product not only must observe the nature structures, but to follow well-defined steps. Naturally, every classic phases of a project should be followed as historic, technology and marketing searching.

The application of the bionics is based in two additional activities. The first is the search of the nature parts, seeking the natural phenomena (physiology, biomechanics, and functions) without to aim immediate application. The second is the search applicated which started from the project problems, and aim on the natural systems principles of solution that can to solve the problems (VASCONCELOS, 2000).

The methodology consists in functional, structural and morphologic matrix analysis as well as the viability of its application (VASCONCELOS, 2000).

Functional Analysis: is the study of the natural system physiology, including functional mechanisms of the natural element; principles which trigger its biomechanics. The issues addressed are: What is the function? How is the functional system?

Morphological Analysis: understand why the sample posses that shape, studying the existence of a geometrical interrelation, observe and understand its texture.

Structural Analysis: study the organization of the parts constituents natural element enabling natural ability of the sample in withstand stresses, check its architecture and natural growth.

Feasibility Analysis: study the possibilities to apply the previous characteristics make in the project of a product. Evaluate every aspects observed (JUNIOR et al., 2009).

Product design as performed by the research methodology applied bionics, becomes effective practice, because the reliability of the results analyzed by the natural evolutionary process (JUNIOR et al., 2009).

However, biological structures are complicated, and we are only now beginning to posses a sophisticated enough tool kit to mimic the salient features of that complexity. We know more about plants and animals work than we used to. It is necessary studying more, for example, animal locomotion, how insects to remain airborne, identify specific structure-function relationships (DICKINSON, 1999).

\section{REFERENCES}

ASHBY, M. F. Materials Selection in Mechanical Design. Butterworth Heinemann, Oxford, UK, 1999, p. 65.

BENYUS, J.M. Biomimicry: Innovation Inspirates by Nature. EUA: Perennial, 1997. 
COHEN, Y.B. Biomimetics: Biologically Inspired Technologies. EUA: CRC, 2005.

DICKINSON, M.H. Bionics: Biological insight into mechanical design. Proceedings of National Academy of Sciences of United States of America [on line]. 1999, v. 96, n.25, p. 14208-14209. Available in:

$<$ http://www.pnas.org/content/96/25/14208.full\#xref-ref-2-1> Access 06 may 2010.

FAVRET, E. A. La Biología Inspira Desarollos Tecnológicos em el Campo de la Ciencia de Los materiales y la Ingeniería. Associacíon Argentina de Materiales. 2008, v. 5, n.1, p. 2-13. Available in: <http://www.materiales-sam.org.ar > Access: 13 mar 2010 .

JUNIOR, W.K.; GUANABARA, A.S.; SILVA, E.A.L., PLATCHECK, E.R. Proposta de uma metodologia para o desenvolvimento de produtos baseados no estudo da biônica. 2009. Available in:

$<$ http://dqsperb.files.wordpress.com/2009/05/metodologia-projetual-com-enfase-embionica.pdf> Access: 23 may 2010.

MEIRA G.L.; HEMANN,A. A natureza como fonte de inspiração para concepção de embalagens sustentáveis. In: I ENCONTRO DE SUSTENTABILIDADE EM PROJETO DO VALE DO ITAJAÍ, ENSUS 12-13 de April. 1-8, 2007.

PATENTS ONLINE. Available in: <

http://www.freepatentsonline.com/y2004/0045075.html> Access: 22 jun 2011.

SUN, X.; XIAO, C. A Study on Bionic Design of Products. Asian Social Science. v. 60, n. 2, p. 92-94, 2007.

VASCONCELOS, A.C. Estruturas da Natureza: Um Estudo da Interface entre Biologia e Engenharia. São Paulo: Studio Nobel, 2000. 312p. 